\title{
Title: Predicting global killer whale population collapse from PCB pollution
}

Authors: Jean-Pierre Desforges ${ }^{1 *}$, Ailsa Hall ${ }^{2 *}$, Bernie McConnell ${ }^{2}$, Aqqalu Rosing Asvid ${ }^{3}$, Jonathan L. Barber ${ }^{4}$, Andrew Brownlow ${ }^{5}$, Sylvain De Guise ${ }^{6}$, Igor Eulaers ${ }^{1}$, Paul D. Jepson ${ }^{7}$, Robert J. Letcher ${ }^{8}$, Milton Levin ${ }^{6}$, Peter S. Ross ${ }^{9}$, Filipa Samarra ${ }^{10}$, Gísli Víkingson ${ }^{10}$, Christian Sonne ${ }^{1}$, Rune Dietz ${ }^{1 *}$.

\section{Affiliations:}

${ }^{1}$ Department of Bioscience, Arctic Research Centre, Aarhus University, Frederiksborgvej 399, PO Box 358, 4000 Roskilde, Denmark

${ }^{2}$ Sea Mammal Research Unit, Scottish Oceans Institute, University of St Andrews, St Andrews, KY16 8LB, United Kingdom

${ }^{3}$ Greenland Institute of Natural Resources, PO Box 570, 3900 Nuuk, Greenland

${ }^{4}$ Centre for Environment, Fisheries and Aquaculture Science, Pakefield Road, Lowestoft, NR33 0HT, United Kingdom

${ }^{5}$ Scottish Marine Animal Stranding Scheme, SRUC Veterinary Services Drummondhill, Stratherrick Road, Inverness, IV2 4JZ, United Kingdom

${ }^{6}$ Department of Pathobiology and Veterinary Science, University of Connecticut, 61 North Eagleville Road, Storrs, Connecticut 06269-3089, United States of America

${ }^{7}$ Institute of Zoology, Zoological Society of London, Regent's Park, London NW1 4RY, United Kingdom

${ }^{8}$ Ecotoxicology and Wildlife Health Division, Environment and Climate Change Canada, National Wildlife Research Centre, Carleton University, Ottawa, Ontario, K1A 0H3, Canada

${ }^{9}$ Ocean Wise Conservation Association, P.O. Box 3232, Vancouver, British Columbia, V6B $3 \mathrm{X} 8$, Canada

${ }^{10}$ Marine and Freshwater Research Institute, Skúlagata 4, 101 Reykjavík, Iceland

*Correspondence to: jpd@bios.au.dk,rdi@bios.au.dk and ajh7@st-andrews.ac.uk. 


\title{
One Sentence Summary:
}

Legacy chemicals threaten killer whales

\begin{abstract}
:
Killer whales (Orcinus orca) are among the most highly polychlorinated biphenyl (PCB)contaminated mammals in the world, raising concern about the health consequences of current exposures. Using an Individual Based Model framework and globally available data on tissue PCB concentrations in killer whales, we show that PCB effects on reproduction and immune function threaten the long-term viability of $>50 \%$ of the world's killer whale populations. PCBmediated effects over the coming 100 years predicted that killer whale populations near industrialized regions, and those feeding at high trophic levels regardless of location, are at high risk of population collapse. Despite their near global ban over 30 years ago, PCBs continue to devastate marine ecosystems.
\end{abstract}

\section{Main Text:}

The widespread industrial and household use of polychlorinated biphenyls (PCBs) during the $20^{\text {th }}$ century led to ubiquitous contamination of the biosphere, with significant harm among different wildlife populations (1). PCBs are toxic anthropogenic compounds shown to impair reproduction, disrupt the endocrine and immune systems, and increase the risk of cancer $(2,3)$. While environmental declines were evident after local and international efforts to phase-out PCBs (4), improvements were short-lived and PCB levels have remain stable in many species since the 1990s (5). Tissue PCB concentrations remain exceedingly high in high trophic-level killer whales (Orcinus orca) and other dolphin species $(5,6$ ). It has been suggested that high PCB concentrations in killer whales may be contributing to observations of low recruitment and population decline, potentially leading to local extinctions $(5,7)$. To date, only one study, focusing on resident killer 
whales in western Canada, has investigated population risk from PCB exposure (8). Exposure modelling predicted protracted health risks in these resident populations over the next century, underscoring the vulnerability of this long-lived species to PCBs (9). With many killer whale populations facing significant conservation pressures there is an urgent need to assess the impact of PCBs on global killer whale populations.

We compiled blubber PCB concentrations (sum-PCBs, $\mathrm{mg} / \mathrm{kg}$ lipid weight) in killer whale populations around the world, and compared these to established concentration-response relationships for reproductive impairment and immunotoxicity-related disease mortality using an Individual-Based Model framework $(8,10)$. This model incorporates published killer whale fecundity and survival data to construct a stable age-structured baseline population. The model then simulates the accumulation and loss of PCBs in blubber through placental and lactation transfer to the fetus and calf as well as prey ingestion after weaning. Simulated PCB concentrations are then evaluated against concentration-response relationships for calf survival and immune suppression. Immunity is linked to survival probability using relationships between immune suppression and disease mortality (11). We then forecast the predicted effects of PCB exposure on killer whale population growth around the world over the next 100 years.

PCB concentrations in killer whales around the world reflect proximity to PCB production and usage, as well as diet and trophic level (Fig. 1, Table S1). Global PCB production (1930 to 1993) was estimated between 1 and 1.5 million tonnes, mostly occurring in the USA ( $50 \%)$, Russia $(\sim 13 \%)$, Germany $(\sim 12 \%)$, France $(\sim 10 \%)$ and the UK $(5 \%)(12,13)$. The global manufacture of PCBs corresponded well with the observed pattern of PCB levels in killer whale populations, which ranged widely from lowest values in Antarctica, $<10 \mathrm{mg} / \mathrm{kg} \mathrm{lw}(14)$, to values above $500 \mathrm{mg} / \mathrm{kg} \mathrm{lw}$ in individuals near the highly industrialized areas of the Strait of Gibraltar, 
the UK, and the Pacific Northeast $(5,15,16)$. Diet contributes importantly to PCB accumulation in killer whales via biomagnification across trophic levels, resulting in sharp differences between populations feeding on marine mammals, tuna (Scombridae) and sharks (Selachimorpha) to those feeding on lower trophic level fish (Fig. 1; Table S1). This is exemplified in the Pacific Northeast where marine mammal-eating transient killer whales carry 10-20 fold higher PCB burdens compared to fish-eating northern residents, despite sharing the same coastline $(15,17)$. Overall, females exhibit lower blubber PCB levels than males due to maternal sequestration to young during foetal development and lactation $(18,19)$. Exceptions have been reported in the most highly PCB-contaminated populations, including the UK, Strait of Gibraltar (5), and transient individuals in the Northeast Pacific (17), suggesting that PCBs may be limiting successful reproduction with the consequence of reducing the maternal loss of PCBs.

Model forecasting over the next 100 years shows the significant potential impact of PCBs on population size and long-term viability of long-lived killer whales around the world (Fig. 2). Killer whale populations with similar PCB levels were grouped together and assigned to exposure groups (10, Fig 2C,D, Table S1). The modelled reference (unexposed) population grew by 141\% (interquartile range $\left.\left(25 / 75^{\text {th }}\right)=96.3-176.5 \%\right)$ over the 100 -year simulation period. The least contaminated populations (group 1) included Alaskan residents, Antarctica type C, Canadian Northern residents, Crozet Archipelago, Eastern Tropical Pacific, and Norwegian populations. These are estimated to accumulate $1 \mathrm{mg} / \mathrm{kg} \mathrm{lw}$ of PCBs per year, resulting in median blubber concentrations of $7.9(4.7-14.0) \mathrm{mg} / \mathrm{kg}$ lw and effects causing a population decrease of $8.8 \%(-4.1$ $25.3 \%)$ or $15.4 \%(3.5-25.2)$ relative to the reference population for reproductive effects alone or combined reproductive and immune effects, respectively. However, while relative populationlevel effects were observed for these low exposed populations, the model still predicts a net 
doubling in their population size over 100 years (Fig. 2C, Fig. S2-S3). Annual PCB accumulation rates of $3,6,9,15,18$, and $27 \mathrm{mg} / \mathrm{kg}$ are represented by exposure groups two through seven, which have incrementally greater blubber PCB levels (Fig. 2C, Table S1). Alaskan offshore, Faroe Islands, and Iceland whales (group 2) have similar PCB burdens (13.9-41.5 mg/kg lw) and are predicted to have modest population growth over the 100-year simulation period, albeit at reduced growth relative to the reference population; modelled PCB effects on reproduction alone or in combination with immune suppression resulted in a population reduction of $22.6 \%(14.0-38.3 \%)$ or $40.5 \%(32.6-48.7 \%)$. Alaskan transient and Canadian Southern resident populations have similar PCB profiles (group 3: $28-83 \mathrm{mg} / \mathrm{kg} \mathrm{lw}$ ), and PCB effects are predicted to inhibit population growth or cause a gradually decline of $\sim 15 \%(-33.9-4.3 \%)$ for reproductive or combined effects, respectively. These represent median reductions of 54.7 and $64.7 \%$ relative to unexposed populations. Greenland, Canary Islands, Hawaii, Japan, Brazil, Northeast Pacific transient, Strait of Gibraltar, and UK populations all possess PCB levels above $40 \mathrm{mg} / \mathrm{kg}$ lw (Fig. 2C), and this level of exposure is predicted to cause population declines at various rates depending on the exposure group. Populations of Japan, Brazil, Northeast Pacific transient, Strait of Gibraltar, and UK are all tending towards complete collapse in our modelled scenarios.

To quantify and compare the global risk of PCB exposure in killer whales, population trajectories from the model were used to calculate potential annual population growth rates $(\lambda)$. The achievable growth rates, incorporating combined PCB effects on both reproduction and immune function, were at or below the growth threshold $(\lambda=1)$ for 10 of the 19 populations for which information on PCB exposure is currently available (Fig. 2D and Table 1). These results suggest that chronic exposure to persistent PCBs has the potential to impact long-term population viability in over half of all studied killer whale populations. Of these, Alaskan transient and Canada 
Southern resident populations are at moderate risk of population-level effects $(\lambda=1)$, while Brazilian, Northeast Pacific transient, Canary Islands, Greenlandic, Hawaiian, Japanese, Strait of Gibraltar, and the UK populations are at high risk of collapse over the next 100 years. The model predicted low PCB risk and stable population growth $(\lambda>1)$ for the remaining nine populations (Fig. 2d and Table 1).

Our global assessment here of PCB-related effects on the long-term viability of killer whale populations represents a fundamental advancement in our understanding of population impacts from chronic exposure to these legacy chemicals in a long-lived marine apex predator. More than 35 years after the onset of the ban of PCBs, killer whales still have PCB concentrations as high as $1300 \mathrm{mg} / \mathrm{kg} \mathrm{lw}$ (24). Killer whales once thrived from pole to pole but, today, only those in the less contaminated waters of the Arctic and Antarctic appear to be able to sustain growth (Table 1) (7, 25). We had no PCB data for killer whales in the Gulf of Mexico, but even before the Deep Water Horizon oil spill in 2010, estimates for killer whales in the region are consistent with a progressive population collapse from 277 individuals in 1991-1994, 133 in 1996-2001, 49 in 2003-2004, and only 28 in 2009 (26). Prey switching from low to high PCB-contaminated prey sources (e.g. fish to seals) has significantly increased PCB exposures in some killer whale populations like Northeast Scotland (UK) and Greenland that are now predicted to collapse (27). This new feeding behaviour may be partly linked to the recovery of seal populations after decades of hunting. Taken together, our results lend credence to the threat facing killer whales from PCBs and highlights how legacy contaminants have potentially devastating consequences for long-lived wildlife populations, even decades after discontinued production.

The status-quo efforts to protect killer whales from conservation threats are likely to fail because PCBs have remained at levels associated with health risks over the past decades $(5,7,9)$. 
Concerted efforts beyond those listed under the Stockholm Convention on POPs are urgently needed to reduce PCB exposure in vulnerable wildlife populations. It is estimated that more than $80 \%$ of global PCB stocks are yet to be destroyed, and at present rates of PCB elimination, many countries will not achieve the 2025 and 2028 targets as agreed upon under the Stockholm such as prey limitations, ship strikes, and underwater noise pollution (25), our assessment here clearly demonstrates the high risk of collapse for many killer whale populations as a consequence of their PCB exposures alone.

\section{References and Notes:}

1. A. M. Roos, B. M. V. M. Bäcklin, B. O. Helander, F. F. Rigét, U. C. Eriksson, Improved reproductive success in otters (Lutra lutra), grey seals (Halichoerus grypus) and sea eagles (Haliaeetus albicilla) from Sweden in relation to concentrations of organochlorine contaminants. Environ. Pollut. 170, 268-275 (2012).

2. R. J. Letcher et al., Exposure and effects assessment of persistent organohalogen contaminants in arctic wildlife and fish. Sci. Total Environ. 408, 2995-3043 (2010).

3. S. H. Safe, Polychlorinated Biphenyls ( PCBs ) : Environmental Impact, Biochemical and Toxic Responses, and Implications for Risk Assessment. Crit. Rev. Toxicol. 24, 87-149 (1994).

4. C. De Wit et al., AMAP Assessment 2002: Persistent Organic Pollutants in the Arctic. (Arctic Monitoring and Assessment Programme., Oslo, Norway, 2004).

5. P. D. Jepson et al., PCB pollution continues to impact populations of orcas and other dolphins in European waters. Sci. Rep. 6, 18573 (2016). 
6. B. C. Balmer et al., Relationship between persistent organic pollutants (POPs) and ranging patterns in common bottlenose dolphins (Tursiops truncatus) from coastal Georgia, USA. Sci. Total Environ. 409, 2094-101 (2011).

7. P. D. Jepson, R. J. Law, Persistent pollutants, persistent threats. Science (80-. ). 352, $1388-1389$ (2016).

8. A. J. Hall et al., Predicting the effects of polychlorinated biphenyls on cetacean populations through impacts on immunity and calf survival. Environ. Pollut. 233, 407418 (2018).

9. B. E. Hickie, P. S. Ross, R. W. Macdonald, J. K. B. Ford, Killer whales (Orcinus orca) face protracted health risks associated with lifetime exposure to PCBs. Environ. Sci. Technol. 41, 6613-9 (2007).

10. Materials and methods are available as supplementary materials at the Science website.

11. M. Luster et al., Risk assessment in immunotoxicology: II. Relationships between immune and host resistance tests. Fundam. Appl. Toxicol. 21, 71-82 (1993).

12. K. Breivik, A. Sweetman, J. M. Pacyna, K. C. Jones, Towards a global historical emission inventory for selected PCB congeners--a mass balance approach. 1. Global production and consumption. Sci. Total Environ. 290, 181-98 (2002).

13. K. Breivik, A. Sweetman, J. M. Pacyna, K. C. Jones, Towards a global historical emission inventory for selected PCB congeners--a mass balance approach 2. Emissions. Sci. Total Environ. 377, 296-307 (2002).

14. M. M. Krahn, R. L. Pitman, D. G. Burrows, D. P. Herman, R. W. Pearce, Use of chemical tracers to assess diet and persistent organic pollutants in Antarctic Type C killer whales. Mar. Mammal Sci. 24, 643-663 (2008). 
15. P. Ross, G. M. Ellis, M. G. Ikonomou, L. G. Barrett-Lennard, R. F. Addison, High PCB Concentrations in Free-Ranging Pacific Killer Whales, Orcinus orca: Effects of Age, Sex and Dietary Preference. Mar. Pollut. Bull. 40, 504-515 (2000).

16. M. M. Krahn et al., Use of chemical tracers in assessing the diet and foraging regions of eastern North Pacific killer whales. Mar. Environ. Res. 63, 91-114 (2007).

17. A. H. Buckman et al., PCB-associated changes in mRNA expression in killer whales (Orcinus orca) from the NE Pacific Ocean. Environ. Sci. Technol. 45, 10194-10202 (2011).

18. J.-P. W. Desforges, P. S. Ross, L. L. Loseto, Transplacental transfer of polychlorinated biphenyls and polybrominated diphenyl ethers in arctic beluga whales (Delphinapterus leucas). Environ. Toxicol. Chem. 31, 296-300 (2012).

19. A. Aguilar, A. Borrell, Reproductive transfer and variation of body load of organochlorine pollutants with age in fin whales (Balaenoptera physalus). Arch. Environ. Contam. Toxicol. 27, 546-54 (1994).

20. É. Poncelet, C. Barbraud, C. Guinet, Population dynamics of killer whales (Orcinus orca) in the Crozet Archipelago, southern Indian Ocean: A mark-recapture study from 1977 to 2002. J. Cetacean Res. Manag. 11, 41-48 (2010).

21. F. I. P. Samarra et al., Movements and site fidelity of killer whales (Orcinus orca) relative to seasonal and long-term shifts in herring (Clupea harengus) distribution. Mar. Biol. 164, 159 (2017).

22. S. Kuningas, T. Similä, P. S. Hammond, Population size, survival and reproductive rates of northern Norwegian killer whales (Orcinus orca) in 1986-2003. J. Mar. Biol. Assoc. United Kingdom. 94, 1-15 (2013). 
23. R. Esteban et al., Using a multi-disciplinary approach to identify a critically endangered killer whale management unit. Ecol. Indic. 66, 291-300 (2016).

24. M. M. Krahn et al., Stratification of lipids, fatty acids and organochlorine contaminants in blubber of white whales and killer whales. J. Cetacean Resour. Manag. 6, 175-189 (2004).

25. International Union for Conservation of Nature, The IUCN Red List of Threatened Species, Version 2015.4 (IUCN, Gland, 2015), (available at www.iucnredlist.org).

26. S. A. Hayes, E. Josephson, K. Maze-Foley, P. E. Rosel, US Atlantic and Gulf of Mexico Marine Mammal Stock Assessments -- 2016. NOAA Tech. Memo. NMFS NE 241; 274 p.

27. D. Vongraven, A. Bisther, Prey switching by killer whales in the north-east Atlantic:

Observational evidence and experimental insights. J. Mar. Biol. Assoc. United Kingdom. 94, 1357-1365 (2014).

28. United Nations Environment Programme. Consolidated assessment of efforts made towards the elimination of polychlorinated biphenyls (Switzerland, 2016; https://wedocs.unep.org/bitstream/handle/20.500.11822/13664/Consolidated PCB Assessment_2016.pdf).

29. Center for International Earth Science Information Network - CIESIN - Columbia University. 2016. Documentation for the Gridded Population of the World, Version 4 (GPWv4). Palisades NY: NASA Socioeconomic Data and Applications Center (SEDAC), (available at http://dx.doi.org/10.7927/H4D50JX4).

30. A. J. Hall et al., Individual-Based Model Framework to Assess Population Consequences of Polychlorinated Biphenyl Exposure in Bottlenose Dolphins. Environ. Health Perspect. 114, 60-64 (2006). 
31. J.-P. Desforges et al., Effects of Polar Bear and Killer Whale Derived Contaminant Cocktails on Marine Mammal Immunity. Environ. Sci. Technol. 51, 11431-11439 (2017).

32. J. E. Yordy et al., Partitioning of persistent organic pollutants between blubber and blood of wild bottlenose dolphins: implications for biomonitoring and health. Environ. Sci. Technol. 44, 4789-95 (2010).

33. S. A. Raverty et al., Respiratory Microbiome of Endangered Southern Resident Killer Whales and Microbiota of Surrounding Sea Surface Microlayer in the Eastern North Pacific. Sci. Rep. 7, 394 (2017).

34. A. M. Schaefer et al., Serological evidence of exposure to selected viral, bacterial, and protozoal pathogens in free-ranging atlantic bottlenose dolphins (Tursiops truncatus) from the Indian River Lagoon, Florida, and Charleston, South Carolina. Aquat. Mamm. 35, $163-170$ (2009).

35. U. Siebert, E. Prenger-Berninghoff, R. Weiss, Regional differences in bacterial flora in harbour porpoises from the North Atlantic: Environmental effects? J. Appl. Microbiol. 106, 329-337 (2009).

36. P. D. Jepson et al., Antibodies to Brucella in marine mammals around the coast of England and Wales. Vet. Rec. 141, 513-515 (1997).

37. R. J. Law, P. D. Jepson, Europe's insufficient pollutant remediation. Science 356, 148 (2017).

38. M. McKinney et al., A review of ecological impacts of global climate change on persistent organic pollutant and mercury pathways and exposures in arctic marine ecosystems. Curr. Zool. 61: 617-628 (2016).

39. D. P. Herman et al., Feeding ecology of eastern North Pacific killer whales Orcinus orca 
from fatty acid, stable isotope, and organochlorine analyses of blubber biopsies. Mar. Ecol. Prog. Ser. 302, 275-291 (2005).

40. G. M. Ylitalo et al., Influence of life-history parameters on organochlorine concentrations in free-ranging killer whales (Orcinus orca) from Prince William Sound, AK. Sci. Total Environ. 281, 183-203 (2001).

41. J. Lailson-Brito, T. L. Bisi, L. G. Vidal, J. Paulo, M. Torres, Organochlorine compound accumulation in delphinids from Rio de Janeiro State, southeastern Brazilian coast. Sci. Total Environ. 433, 123-131 (2012).

42. D. Hayteas, D. Duffield, High Levels of PCB and p, p'-DDE Found in the Blubber of Killer Whales ( Orcinus orca). Mar. Pollut. Bull., 558-561 (2000).

43. M. Noël, L. Barrett-Lennard, C. Guinet, N. Dangerfield, P. S. Ross, Persistent organic pollutants (POPs) in killer whales (Orcinus orca) from the Crozet Archipelago, southern Indian Ocean. Mar. Environ. Res. 68, 196-202 (2009).

44. M. J. Bachman, J. M. Keller, K. L. West, B. A. Jensen, Persistent organic pollutant concentrations in blubber of 16 species of cetaceans stranded in the Pacific Islands from 1997 through 2011. Sci. Total Environ. 488-489, 115-123 (2014).

45. N. Kajiwara et al., Organohalogen and organotin compounds in killer whales massstranded in the Shiretoko Peninsula, Hokkaido, Japan. Mar. Pollut. Bull. 52, 1066-1076 (2006).

46. M. Ono, N. Kannan, T. Wakimoto, R. Tatsukawa, Dibenzofurans a greater global pollutant than dioxins? Evidence from analyses of open ocean killer whale. Mar. Pollut. Bull. 18, 640-643 (1987).

47. S. Tanabe, N. Kannan, A. Subramanian, S. Watanabe, R. Tatsukawa, Highly toxic 
coplanar PCBs: Occurrence, source, persistency and toxic implications to wildlife and humans. Environ. Pollut. 47, 147-163 (1987).

48. H. Wolkers, P. Corkeron, S. Van Parijs, T. Simila, B. van Bavel, Accumulation and transfer of contaminants in killer whales (Orcinus orca) from Norway: Indications for contaminant metabolism. Environ. Toxicol. Chem. 26, 1582-1590 (2007).

49. L. A. Vélez-Espino et al., "Comparative demography and viability of northeastern Pacific resident killer whale populations at risk. Canadian Technical Report of Fisheries and Aquatic Sciences 3084” (Nanaimo, BC, 2014).

50. M. Taylor, B. Plater, "Population Viability Analysis for the Southern Resident Population of the (Orcinus orca)" (Tucson, Arizona, 2001).

51. P. F. Olesiuk, M. a Bigg, G. M. Ellis, Life history and population dynamics of resident killer whales (Orcinus orca) in the coastal waters of British Columbia and Washington State. Reports Int. Whal. Comm. (1990), pp. 209-243.

52. C. O. Matkin, J. Ward Testa, G. M. Ellis, E. L. Saulitis, Life history and population dynamics of southern Alaska resident killer whales (Orcinus orca). Mar. Mammal Sci. 30, $460-479$ (2014).

53. P. Tixier et al., Demographic consequences of fisheries interaction within a killer whale (Orcinus orca) population. Mar. Biol. 164, 170-186 (2017).

54. R. Esteban et al., Dynamics of killer whale, bluefin tune and human fisheries in the strait of Gibraltar. Biol. Conserv. 194, 31-38 (2016).

55. T. R. Robeck, K. Willis, M. R. Scarpuzzi, J. K. O’Brien, Comparisons of life-history parameters between free-ranging and captive killer whale ( Orcinus orca ) populations for application toward species management. J. Mammal. 96, 1055-1070 (2015). 
Acknowledgments: The authors thank all persons involved in the killer whale sampling necessary to determine PCB concentrations as well as Tinna Christensen for help producing the manuscript figures. Funding: This research was supported by grants to J.P.D from the Canadian National Science and Engineering Research Council (NSERC) (PGSD3-443700-2013), Aarhus University’s Graduate School and Science and Technology (GSST) and Department of Bioscience; and funding from the Danish DANCEA programme (MST-112-00171 and MST112-00199), the Defra, Scottish and Welsh Governments (for CSIP/SMASS/CEFAS), and the Icelandic Research Fund (i. Rannsóknasjóður) START Postdoctoral Fellowship (grant number 120248042). This paper is a contribution from the BONUS BaltHealth project, which has received funding from BONUS (Art. 185), funded jointly by the EU, Innovation Fund Denmark, Forschungszentrum Jülich GmbH, German Federal Ministry of Education and Research (grant number FKZ 03F0767A), Academy of Finland (decision \#311966) and Swedish Foundation for Strategic Environmental Research. Author contributions: J.P.D., A.H., R.D, C.S., and I.E. designed the study. R.D., A.R.A, G.V., F.S., R.L., J.L.B., A.B., P.S.R., and P.D.J. provided samples or performed the contaminant analysis. J.P.D, M.L., S.D., I.E., and R.L performed the cocktail extractions and immunological experiments. J.P.D. collected the data. A.H. and B.M. developed and ran the model. J.P.D. generated figures and performed all data analyses. All authors were involved in interpretation of results and writing the manuscript. Competing interest: The authors declare no competing interests. Data and materials availability: All data are available in the manuscript or the supplementary material.

\section{Supplementary Materials:}

Materials and Methods 
Figures S1-S3

Tables S1-S2

References (30-56)

Fig. 1. Global PCB concentrations in killer whales. A. Conceptual model of PCB bioaccumulation and magnification leading to elevated PCB concentrations in killer whale populations. B. Global overview of PCB concentrations in killer whale blubber. Light and dark green circles represent males and females, respectively. Also shown is population densitynormalized cumulative global usage of PCBs per country from 1930 to 2000 (12). Number labels indicate populations with measured PCB concentrations (Table S1).

Fig. 2. Simulated killer whale population size in response to reproductive and immune effects of PCB exposure. A. Calf survival as a function of maternal adipose PCB lipid weight concentration. B. Immune suppression as a function of blubber PCB lipid weight concentration. C. Simulated effect of PCB exposure on population size ( $\%$ initial size, $\left.\mathrm{N}_{0}\right)$ of killer whales over the next 100 years. Simulations include the unexposed reference population (black), effects on reproduction (red), and combined effects on reproduction and immunity (blue). Bold lines and shading represent the median and interquartile range. Each plot represents a different PCB exposure group noted by the interquartile range of PCB concentrations in each panel (10). D. Annual population growth rates $(\lambda)$ for modelled populations according to exposure group.

Table 1. Global assessment of population-level risk from PCB exposure. 


\begin{tabular}{|c|c|c|c|c|}
\hline PCB risk & Population & Location & $\begin{array}{c}\text { Population } \\
\text { size }\end{array}$ & Protection status \\
\hline $\begin{array}{c}\text { Low } \\
(\lambda>1)\end{array}$ & $\begin{array}{l}\text { Alaska offshore } \\
\text { Alaska resident } \\
\text { Antarctica type C } \\
\text { Canada North resident } \\
\text { Crozet Archipelago } \\
\text { Eastern Tropical Pacific } \\
\text { Faroe Islands } \\
\text { Iceland } \\
\text { Norway }\end{array}$ & $\begin{array}{l}\text { North Pacific } \\
\text { North Pacific } \\
\text { Southern Ocean } \\
\text { North-East Pacific } \\
\text { South Indian Ocean } \\
\text { Tropical Pacific } \\
\text { North-East Atlantic } \\
\text { North Atlantic } \\
\text { North-East Atlantic }\end{array}$ & $\begin{array}{c}200^{\dagger} \\
2347^{\dagger} \\
\text { unknown } \\
290^{\ddagger} \\
37-98^{\S} \\
8500^{\dagger} \\
\text { unknown } \\
376^{\oplus} \\
500-1100^{£}\end{array}$ & $\begin{array}{c}\text { none }^{\dagger} \\
\text { none }^{\dagger} \\
\text { unknown } \\
\text { threatened } \\
\text { unknown } \\
\text { unknown } \\
\text { unknown } \\
\text { NA } \\
\text { unknown }\end{array}$ \\
\hline $\begin{array}{c}\text { Moderate } \\
(\lambda=1)\end{array}$ & $\begin{array}{l}\text { Alaska transient } \\
\text { Canada South resident }\end{array}$ & $\begin{array}{l}\text { North Pacific } \\
\text { North-East Pacific }\end{array}$ & $\begin{array}{l}587^{\dagger} \\
78^{\star}\end{array}$ & $\begin{array}{c}\text { none/depleted }^{\dagger} \\
\text { endangered }\end{array}$ \\
\hline $\begin{array}{l}\text { High } \\
(\lambda<1)\end{array}$ & $\begin{array}{l}\text { Brazil } \\
\text { Northeast Pacific transient } \\
\text { Canary Islands } \\
\text { Greenland } \\
\text { Hawaii } \\
\text { Japan } \\
\text { Strait of Gibraltar } \\
\text { United Kingdom }\end{array}$ & $\begin{array}{l}\text { South-West Atlantic } \\
\text { North-East Pacific } \\
\text { Atlantic Ocean } \\
\text { North Atlantic } \\
\text { Tropical Pacific } \\
\text { North-West Pacific } \\
\text { Mediterranean } \\
\text { North-East Atlantic }\end{array}$ & $\begin{array}{l}\text { unknown } \\
521^{\dagger} \\
\text { unknown } \\
\text { unknown } \\
101^{\dagger} \\
\text { unknown } \\
\quad 36^{\ddagger} \\
\leq 9^{\Psi}\end{array}$ & $\begin{array}{c}\text { unknown } \\
\text { none }^{\dagger} / \text { threatened }^{\ddagger} \\
\text { unknown } \\
\text { none } \\
\text { none }^{\dagger} \\
\text { unknown } \\
\text { vulnerable }^{\ddagger} \\
\text { none }\end{array}$ \\
\hline
\end{tabular}

Risk categories were set based on predicted growth rates $(\lambda)$ and significant difference using a one-sample t-test against a reference of no growth $(\lambda=1)$ : low risk $(\lambda>1$, little to no effect on population growth), moderate risk ( $\lambda=1$, stagnant population growth), high risk $(\lambda<1$, population decline).

${ }^{\dagger}$ National Oceanographic and Atmospheric Administration (NOAA) stock assessment reports (http://www.nmfs.noaa.gov/pr/sars/species.htm\#smallwhales); AT1 transients in Alaska are a subgroup considered depleted under the US Marine Mammal Protection Act

$\$$ Government of Canada, Species at Risk Public Registry (http://www.sararegistry.gc.ca/default.asp?lang=en\&n=24F7211B-1)

$\S(20)^{`}(21)^{£}(22){ }^{\ddagger}(23){ }^{\Psi}(5)$ 